\title{
石炭溶剤抽出成分の添加によるコークス強度 向上のメカニズム
}

\author{
上岡 健太**小谷野 耕二*・鷹觜 利公*・深田 喜代志*2・大田 晃平*3
}

Addition Effects of Coal Extract Fractions on Coke Strength

Kenta Ueoka, Koji Koyano, Toshimasa TaKanohashi, Kiyoshi FuKada and Kohei Ota

Synopsis : Coal extract fractions were blended with coals, and their effects on coke strength were evaluated. Since the pyridine-soluble (PS) fraction of coal has a high thermoplasticity, its addition to a slightly-caking Kouryusho (KRS) coal greatly increased the strength of cokes. While, by the addition of the pyridine-insoluble (PI) fraction, the strength of cokes was decreased. The reason for decrease may be decline of thermoplasticity due to the PI addition, since its thermoplasticity is significantly low.

Key words : coal extract; coke strength; pyridine soluble fraction; pyridine insoluble fraction; thermoplasticity; anisotropy.

\section{1. 緒言}

近年，逼迫した鉄鋼需要の影響から粘結炭の価格は高騰 しており，2008年の粘結炭の価格は2005年の2倍となっ た ${ }^{1)}$ 。さらに，温暖化問題による炭酸ガス削減の観点から エネルギー消費を削減するために高炉の安定操業が求めら れており，日本の鉄鋼業において通気・通液性を維持する 高強度コークスの安価でかつ安定した供給が求められてい る。原料炭価格の高騰，さらに原料炭資源の枯渇問題に対 応するため, 非微粘結炭を多量に含む石炭配合から高強度 コークスを作成する技術が強く望まれている。このような 要求を満たすには，さまざまな種類の石炭間でのコークス 化を制御し, 非微粘結炭と粘結炭の化学的・物理的相互作 用を理解し，その配合炭の溶融メカニズムを明らかとする ことが重要である。

近年, 粘弾性試験により石炭の溶融性を評価することが 提案されており, 石炭の溶融温度域が重なると溶融性が改 善されることが報告されている ${ }^{2,3)}$ 。また, 工業溶剤を用 いた熱時抽出によりハイパーコール（以下，HPCと表記） と呼ばれる無灰炭が製造開発され, このHPCが幅広い軟 化溶融温度域と優れた溶融性を持つため, それを高強度 コークス製造のための粘結補填材として利用する試みが検 討されている

本研究では, HPC成分の一部であるピリジン可溶成分 とピリジン不溶成分の二つの異なる抽出成分をそれぞれ原 料炭に添加し，コークス強度に与える影響を検討した。具
体的には各溶剂抽出成分を添加した配合炭の溶融性を動的 粘弾性試験により評価を行い，配合炭から作成したコーク スに対して, 間接引張り試験, 気孔構造計測ならびに偏光 顕微鏡観察による光学的組織の定量化により評価を行い， 各抽出成分によるコークス強度向上効果のメカニズムにつ いて検証した。

\section{2. 実験}

\section{$2 \cdot 1$ 石炭試料}

Table 1 に使用した原料炭の性状を示す。粘結炭である K-9炭 (K9)ならびに Goonyella炭(GO), 非微粘結炭である Kouryusho 炭(KRS) 石炭試料として用いた。石炭試料は 1 $\mathrm{mm}$ 以下の試料に粉砕し, $80^{\circ} \mathrm{C}$ で 12 時間真空乾燥後, コークス原料炭として使用した。

\section{$2 \cdot 2$ 溶剤抽出成分の調製}

Fig. 1 に溶剤抽出による石炭抽出成分の調製方法の概略 を示す。室温において二硫化炭素/N-メチル2-ピロリジノ ン $\left(\mathrm{CS}_{2}-\mathrm{NMP}\right.$, 体積比 $\left.1: 1\right)$ 混合溶媒により Upper Freeport

Table 1. The proximate and ultimate analyses of coal samples.

\begin{tabular}{c|ccc|ccccccc}
\hline Sample & \multicolumn{1}{|c|}{ Proximate $(\mathrm{wt} \%, \mathrm{db})$} & \multicolumn{1}{|c}{ Ultimate (wt\%,daf) } \\
& VM & Ash & FC & C & H & N & S & O* & H/C & O/C \\
\hline K9 & 18.2 & 9.5 & 72.3 & 90.5 & 4.6 & 0.9 & 0.1 & 3.9 & 0.61 & 0.03 \\
GO & 24.4 & 8.5 & 67.1 & 88.0 & 4.9 & 1.9 & 0.5 & 4.7 & 0.67 & 0.04 \\
KRS & 31.9 & 8.1 & 60.0 & 83.2 & 5.2 & 1.6 & 0.3 & 9.7 & 0.75 & 0.09 \\
*By difference.
\end{tabular}

平成 21 年 8 月 31 日受付 平成 21 年 12 月 5 日受理 (Received on Aug. 31, 2009; Accepted on Dec. 5, 2009)

* (独) 産業技術総合研究所 (National Institute of Advanced Industrial Science and Technology, 16-1 Onogawa, Tsukuba Ibaraki 305-8569)

* 2 JFE スチール (株) スチール研究所 (Steel Research Laboratory, JFE Steel Corporation)

*3 関西熱化学 (株) 研究開発センター (The Kansai Coke \& Chemicals Corp., Ltd.) 


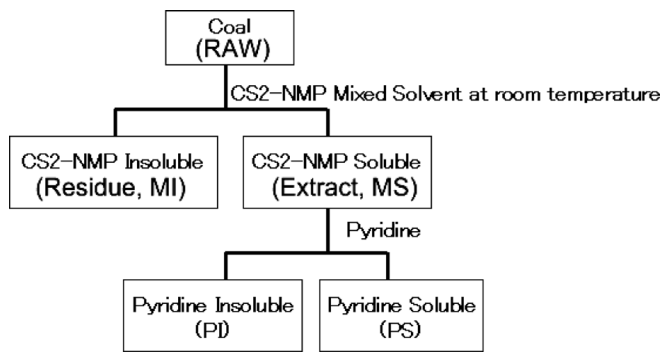

Fig. 1. Preparation of extract fractions by extraction of Upper Freeport bituminous coal at room temperature.

Table 2. The ultimate analysis and yield of extract fractions.

\begin{tabular}{l|ccccc|cc|c}
\hline & \multicolumn{6}{|c|}{ Ultimate analysis [wt\%, daf] } & \multicolumn{3}{|c|}{ Atomic ratio } & \\
\hline Fraction & $\mathrm{C}$ & $\mathrm{H}$ & $\mathrm{N}$ & $\mathrm{S}$ & $\mathrm{O}^{\mathrm{a})}$ & $\mathrm{H} / \mathrm{C}$ & $\mathrm{O} / \mathrm{C}$ & Yeild \\
\hline RAW & 86.2 & 5.1 & 1.9 & 2.2 & 4.6 & 0.71 & 0.04 & - \\
PS & 81.4 & 5.0 & 2.5 & 2.2 & 8.9 & 0.77 & 0.08 & 41.9 \\
PI & 82.9 & 4.8 & 2.5 & 1.9 & 7.9 & 0.70 & 0.07 & 24.6 \\
\hline
\end{tabular}

a) By difference

炭を室温で抽出し，可溶成分を回収した6)。先の抽出成分 をさらにピリジンによる溶剤分別を行い，ピリジン可溶分 (PS) とピリジン不溶分 $(\mathrm{PI}) に$ 分離した。回収したPSならび にPI成分はアセトンで洗浄した後, $80^{\circ} \mathrm{C}$ で 12 時間真空乾 燥を行い，コークス添加試料として用いた。Table 2に Upper Freeport炭PSならびにPI成分の元素分析值および収 率を示す。

Fig. 2 に各抽出成分の軟化溶融性の予備試験結果を示す。 本研究に打いて添加物として使用寸る2つの抽出成分 PS,

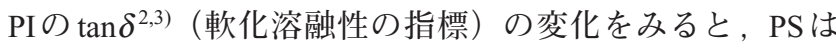
広い温度域において優れた溶融性を示すが，同じ抽出成分 でもPIは原炭よりもかなり低い溶融性を示す成分である ことがわかる。しかしながら，PIはPSに比べて芳香環サ イズが大きく，平均分子量も高いことが既往の研究により 報告されており7), 重質的な成分の添加効果として炭素組 織を発達させる可能性があることが期待される。

そこで本研究では, PSは粘結性が十分ではないKRS炭 に，PIは粘結性がよい配合である KRS(25 wt \%)-GO(35 $\mathrm{wt} \%)-\mathrm{K} 9(40 \mathrm{wt} \%)$ にO 炭の振替で添加し，それぞれの強 度向上効果について調べた。

\section{$2 \cdot 3$ 気孔構造計測}

Fig. 3にコークスの気孔形状に関する計測項目について の模式図を示す。図に示す絶対最大長と円形度を評価の対 象とした。気孔構造計測用の試料は, 間接引張り試験後の 残試料を樹脂埋めし，それを研磨した試料に対して，寸法 $2.03 \mathrm{~cm} \times 1.52 \mathrm{~cm}$ の画像 2 枚を解析画像として使用した。

絶対最大長とは気孔の輪郭画素において2点の画素を抽 出し, その距離が最大となる長さをいい, 今回の計測では 気孔径に相当するものとして計測している。したがって， 絶対最大長の大きな気孔ほど粗大な気孔とし, 強度に及ぼ

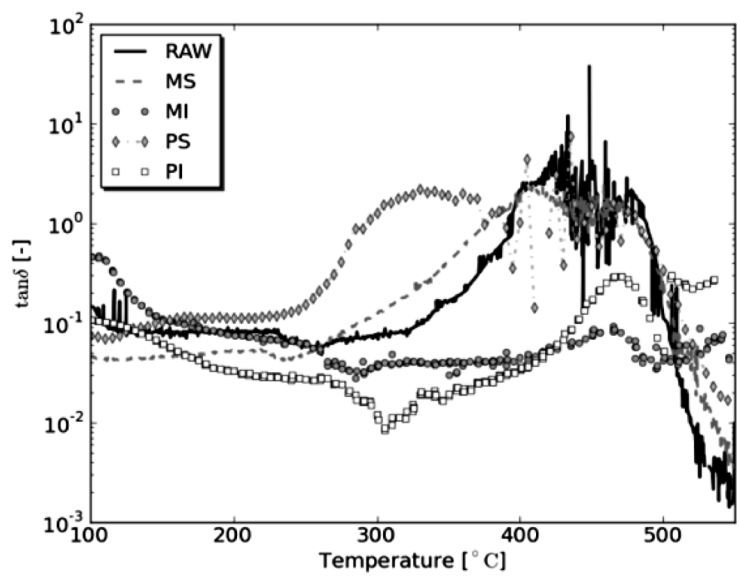

Fig. 2. Thermoplasticity of Upper Freeport raw coal (RAW), its extract fractions (MS, PS and PI) and residue (MI).
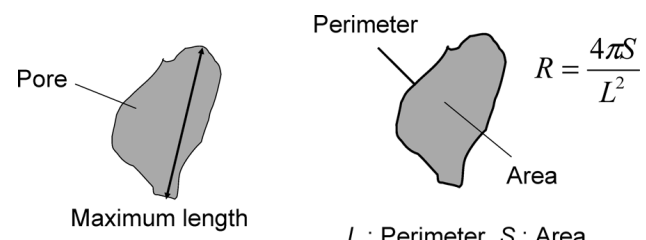

$L$ : Perimeter, $S$ : Area

$R$ : Roundness

Fig. 3. The diagram of pore analysis.

す影響の因子として評価することができる ${ }^{8)}$ 。

円形度とは気孔の形状が円にどれだけ近いかを評価する 量として定義され，気孔の周囲長 $L$ と面積 $S$ を用いて円形 度 $R$ は次式のように定義される。

$$
R=\frac{4 \pi S}{L^{2}}
$$

円形度 $R$ の定義域は $0<R \leq 1$ であり, 值が 1 に近づくほ ぞ円形状に近い形状であり, 応力集中が発生しにくい形状 といえ, 逆に值が 0 に近いほど気孔形状では円形状から遠 のいた複雑で応力集中が発生しやすい形状といえ, 強度を 低下させる因子と評価することができる ${ }^{8,9}$ 。

\section{$2 \cdot 4$ 光学組織の観察}

偏光顕微鏡 (Leica Microsystems, Leica DM2500P) を用い て 500 倍率の下, カウント領域を 200 点として組織形状と 大きさから光学組織を分類し，その存在割合を測定した。 等方性組織のほか, 異方性組織である微粒モザイク, 粗粒 モザイク，繊維状構造ならびに葉片状構造に分類した ${ }^{10}$ 。

\section{$2 \cdot 5$ 動的粘弾性試験}

配合炭ならびに抽出成分を添加した試料に対して動的粘 弾性試験を行い, 軟化溶融性の変化を調べた。約 $0.4 \mathrm{~g} の$ 配合炭試料から, $100 \mathrm{MPa}$ の荷重条件下で径 $13.1 \mathrm{~mm}$, 厚 さ $2 \mathrm{~mm}$ の試験ペレットを準備し，これを測定試料とした。 昇温速度 $3^{\circ} \mathrm{C} / \mathrm{min}$, 窒素流量 $80 \mathrm{~L} / \mathrm{min}$ において $40 \sim 550^{\circ} \mathrm{C} の$ 温度域で測定を行った。 


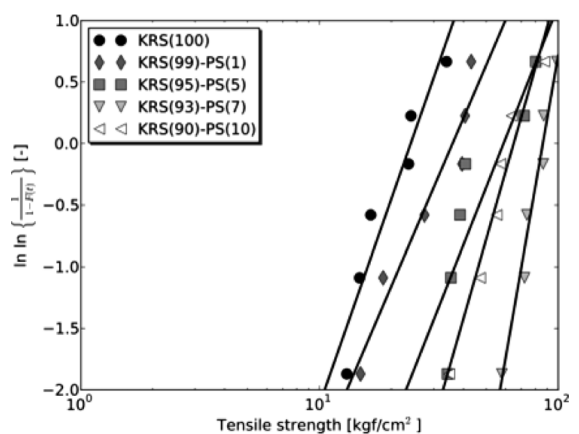

(a) Weibull plot

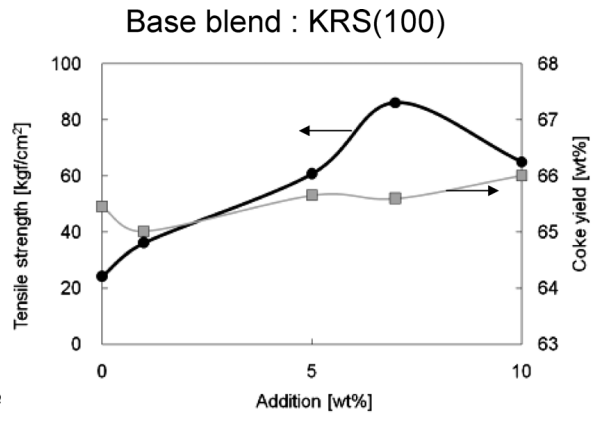

(b) Tensile strength and coke yield

Fig. 4. Tensile strength and coke yield of cokes versus the additive amount of PS.

\section{$2 \cdot 6$ 間接引張り試験}

コークス試料の作製を次のように行った。内径 $20 \mathrm{~mm} の$ ステンレス管に $0.8 \mathrm{~g} / \mathrm{cm}^{3}$ のかさ密度になるように配合炭を 充填し，ステンレス管上部に錘を載せて試料に 0.079 $\mathrm{kgf} / \mathrm{cm}^{2}$ の荷重がかかるようにした。次にマッフル炉にて ステンレス管を室温から $3^{\circ} \mathrm{C} / \mathrm{min}$ の昇温速度で加熱を行 い, $1000^{\circ} \mathrm{C}$ に達した後 30 分間保持し, その後加熱を終了 して室温まで自然冷却した後に, コークスをステンレス管 から取り出した。

得られたコークス試料を切断し, 紙ヤスリにより形状を 整え, 厚さ $5 \mathrm{~mm}$, 直径 $19 \mathrm{~mm}$ の間接引張り試験用の試料 を2 個準備した ${ }^{11,12)}$ 。1 条件の配合炭試料に対して6個の試 験試料を用意し, 間接引張り試験にて引張強度の測定を 行った。測定した強度データを用いてワイブルプロット ${ }^{13)}$ を作成し, ワイブルプロットの分布関数における縦軸の值 （たとえば図4(a)参照）が，0のときに相当する尺度母数の 值を代表強度として定め, 各試料間強度の有意差を比較し た。

\section{3. 結果と考察}

\section{3・1 PSの添加効果}

Fig. 4 にPS成分の添加量に対するコークス引張強度のワ イブルプロット (a), ならびに代表強度と歩留まりの結果 (b)を示す。ワイブルプロットの結果から, PS添加量の増 加に伴いコークス強度は向上し, また強度のばらつきも小 さくなる傾向がみられた。代表強度の変化から，7 wt\%の 添加量で強度向上効果が最大となった。一方, $10 \mathrm{wt} \%$ の 添加では, $7 \mathrm{wt} \%$ 添加時に比べてコークス強度が若干低下 した。また, 歩留まりに関してはPSの添加量を増やして も大きな変化はみられず, $10 \mathrm{wt} \%$ までの添加では歩留ま りが低下することはなかった。この強度向上効果はPSの 優れた溶融性がもたらした効果と考えられ，10 wt\%の添 加では溶融性が過多となって膨張による大きな気孔が生じ たため強度が低下したのではないかと考えられる。

ここで, PSの添加による軟化溶融性向上について検証

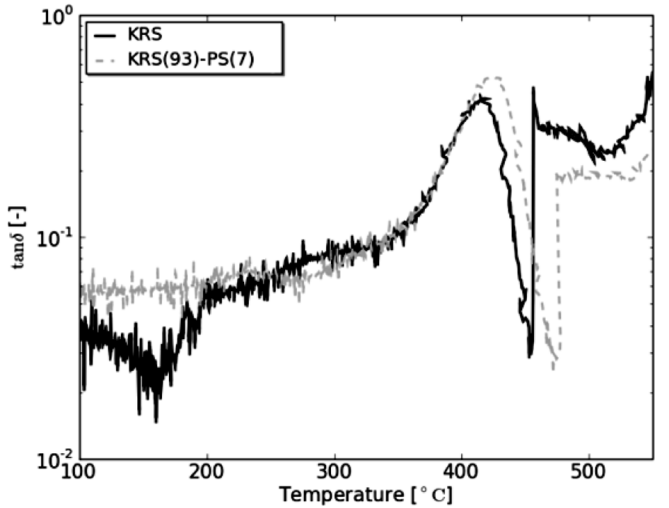

Fig. 5. Dynamic viscoelastic measurement of KRS coal with/without PS.

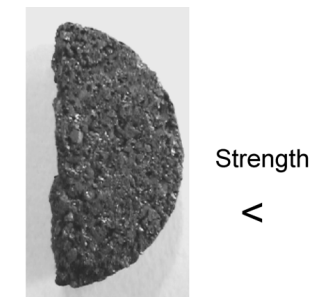

(a) KRS(100) Surface roughness : Big

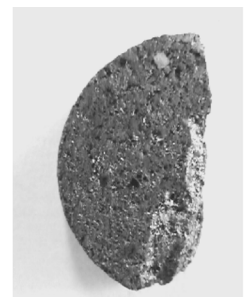

(b) KRS(93)-PS(7)

Surface roughness : Small
Fig. 6. Photographs of cokes with/without PS.

するため，KRS炭ならびに KRS 炭にPSを $7 \mathrm{wt} \%$ 添加した 試料の動的粘弾性試験を行った。Fig. 5 にその結果を示す。 PSの添加により溶融温度域が高温域まで広がるとともに, 軟化溶融性の指標である $\tan \delta$ の最大值が向上しており, 系内の軟化溶融性が大きく向上していることが確認でき た。

Fig. 6にKRS炭のみで作製したコークスとPSを $7 \mathrm{wt} \%$ KRS 炭に添加したコークスの写真を示す。KRS単味炭か ら作製したコークスは表面が粗く，一方，PSを添加した コークスは表面が緻密な様子を示している。

次にこの表面の差異を定量化するために, 偏光顕微鏡に より撮影した画像に対して気孔構造計測を行った。Fig. 7 に解析結果を示す。添加量の増加に伴い，円形度の小さな 
(a) Roundness of pore

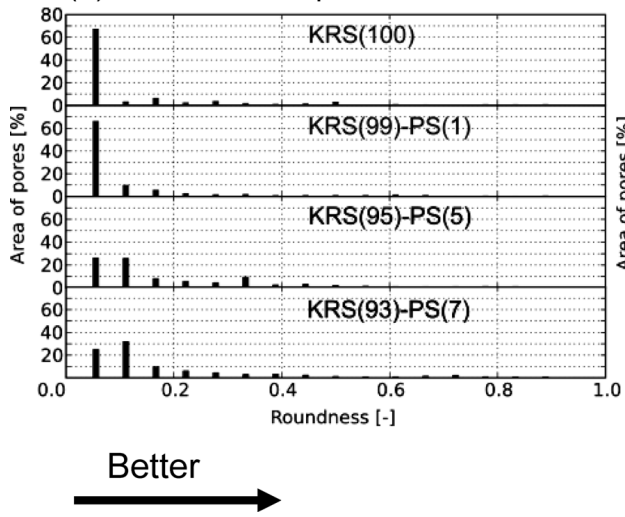

(b) Maximum length of pore

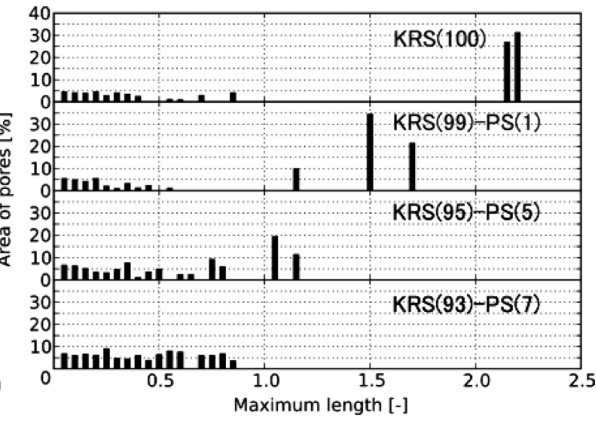

Better

Fig. 7. Analytical results of pore analysis.

気孔の存在割合ならびに絶対最大長の大きな気孔が減少し ている。これはPSの添加により軟化溶融性が向上し, 軟 化溶融以降のコークス化過程において粗大な気孔が減少し たことによるものと考えられる。したがって, PSの添加 により, 形成される気孔構造に大きな変化が生じたことが 示された。

次に偏光顕微鏡観察により光学的組織の割合について検 討を行った。Fig. 8にその結果を示す。KRS炭単味の場合 は石炭化度が低いため, コークス化時の炭素組織が発達し にくく, 光学的等方性組織が 8 割以上を占めている。これ に対して, PSの添加量の増加に伴い, 炭素組織の発達し た光学的異方性組織の割合が増加し, その増加割合はPS の添加割合よりも大きい結果となった。これはPSの添加 によりKRS炭の軟化溶融性が向上し, 軟化溶融時に生成 する液相割合が増加することで構成分子間の再配向が進 み，異方性を持つ炭素組織が増えたためであると考えられ る ${ }^{14)}$ 。

\section{$3 \cdot 2 \mathrm{PI}$ の添加効果}

Fig. 9にPI成分の添加量に対するコークス強度ワイブル プロット (a), ならびにその代表強度と歩留まりの結果(b) を示す。PIの添加においてはコークス強度が $1 \mathrm{wt} \%$ の添加 において強度が若干減少したが, 添加量を $5 \mathrm{wt} \%$ に増加し てもさらなる強度低下はみられず，また強度のばらつきも 添加量によって変化しなかった。PIの添加によるコークス 強度の低下要因は，Fig. 2 に示したようにPI自身の極めて 低い軟化溶融性によるものと考えられるが， $5 \mathrm{wt} \%$ の添加 に打いてさらなる低下がみられなかった。

上記の PIの添加効果を検証するため, PI添加による軟 化溶融性の変化を動的粘弾性試験により調べた。Fig.10に, ベース配合炭と，これにPIを $1 \mathrm{wt} \%$ および $5 \mathrm{wt} \%$ 添加した 配合炭の動的粘弾性試験の結果を示す。PIの添加により $\tan \delta$ の最大值が大きく減少して打り, 添加により系内の軟 化溶融性が大幅に減少することが確認できた。しかしなが ら, $1 \mathrm{wt} \%$ と $5 \mathrm{wt} \%$ では $\tan \delta$ の值がほとんど変化せず, 粘

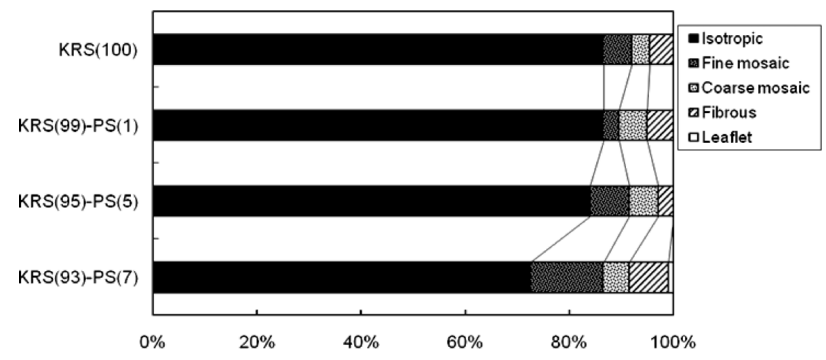

Fig. 8. Optical texture analysis of cokes with/without PS.

結炭である GO炭を減らして $1 \mathrm{wt} \%$ から $5 \mathrm{wt} \%$ へと PI添加 量が大きくなっても $\tan \delta$ の最大值は減少しないという結 果となった。

次にPIの添加によるコークスの炭素組織への影響を検 証するため, 光学的異方性組織を調べた。Fig.11に光学的 組織観察の測定対象とした画像の一例を示す。画像におい て黒色の領域は気孔，その他のグレーから白色の領域は基 質を示しており, 白色に近い領域ほど反射率が高い光学的 異方性組織を示している。PIを添加した試料の画像は, PI 無添加の画像に比べて明らかに白色領域が多いことが確認 でき, PIの添加により視覚的にも炭素組織が発達している ことが確認できた。Fig.12にはそれらの光学的組織割合を 示す。PIの添加により光学的異方性組織の割合が増加し, 特に光学的異方性組織の中でも異方性単位寸法の大きな組 織の割合（繊維状構造，葉片状構造）が増加している。

既往の研究より, 基質の弾性係数は光学的組織には依存 しないこと ${ }^{15}$ が報告されており, 異方性組織の発達は基質 強度に寄与するものではなく, 相互溶融によりコークス強 度に関わる気孔構造が改善されたことによる間接的な強度 向上効果を意味していると考えられる。一方, コークス強 度は光学的異方性組織が発達するほど, 強度が向上するこ とが報告されて打り ${ }^{16)}$, 本研究でのPIの添加効果と一致 している。

以上の結果から, PIの添加効果として, 添加により溶融 性を低下させる一方で，その一部が配合炭と相互溶融する 


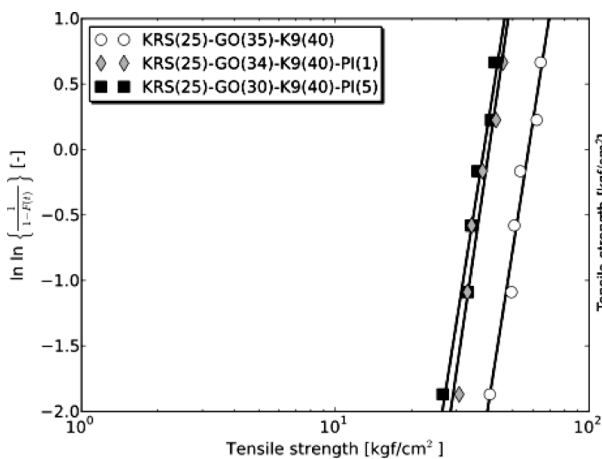

(a) Weibull plot

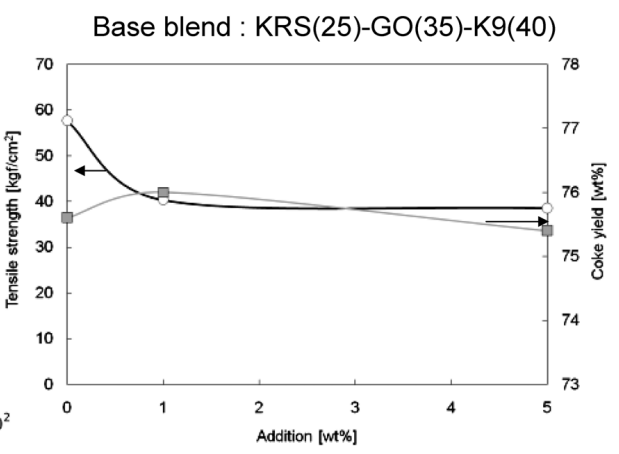

(b) Tensile strength and coke yield

Fig. 9. Tensile strength and coke yield of cokes versus the additive amount of PI.

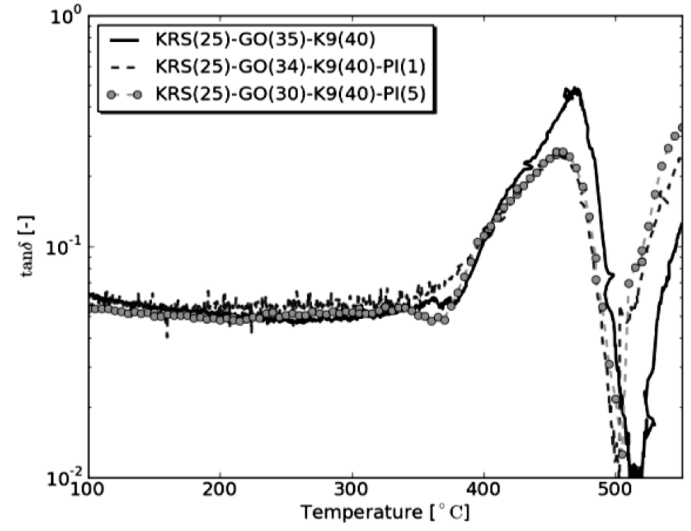

Fig. 10. Dynamic viscoelastic measurement of the coal bled with/without PI.

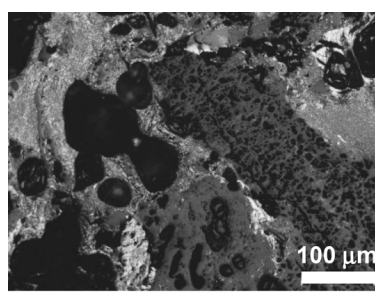

(a) KRS(25)-GO(35)-K9(40)

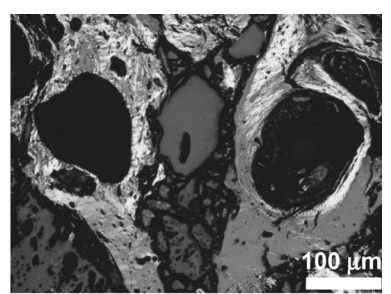

(b) KRS(25)-GO(30)-K9(40)-PI(5)
Fig. 11. Polarization microscope pictures of semiokes with/without PI.

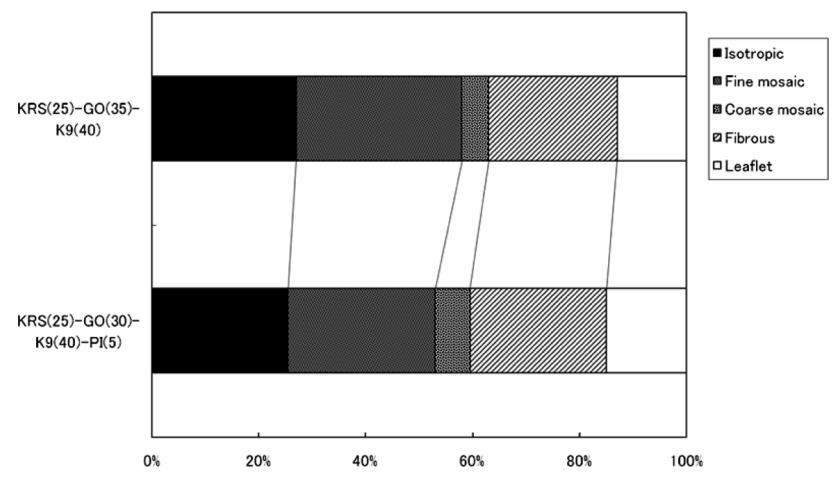

Fig. 12. Optical texture analysis of cokes with/without PI.
ことにより，光学的異方性組織の増加に寄与し，それが系 内のコークス強度の維持に作用する効果を有するものと考 えられる。

\section{4. 結言}

瀝青炭の溶剂抽出成分であるピリジン可溶成分(PS)なら びピリジン不溶成分 $(\mathrm{PI})$ を原料炭に添加し，コークス強度 に与える影響を検討した。その結果，以下のような知見が 得られた。

（1）PS成分の配合炭への添加は，軟化溶融性を大きく 向上させる働きがある。

(2) PS成分の添加によるコークス強度向上機構は, 軟 化溶融性の向上により相互に溶融することで基質の連結性 が促進され, 結果として粗大気孔が減少し, また炭素組織 が発達することで, 全体として強度の高いコークスが形成 される。

（3） PIの $1 \mathrm{wt} \%$ の少量の添加でコークス強度を低下さ せるが， $5 \mathrm{wt} \%$ の添加ではさらなる強度の減少は起こらな い。

（4）PI成分の添加は軟化溶融性を減少させるが，その 一部が配合炭と相互溶融することにより，光学的異方性組 織の増加に寄与し，それが系内のコークス強度を維持す る。

本研究は高強度・高反応性コークス製造技術研究会 (平 成 18 21 年, 日本鉄鋼協会，主査：三浦孝一教授（京都 大学)）における研究成果であり，謝意を表す。

\section{文献}

1 ) BP Statistical Review of World Energy June 2009, BP p.1.c., London, (2009), 32.

2 ) T.Takanohashi, T.Yoshida, M.Iino and K.Kato: Fuel, 78 (1999), 865.

3 ) S.Nomura, K.Kato, I.Komaki, Y.Fujioka, K.Saito and I.Yamaoka: Fuel, 78 (1999), 1583.

4 ) T.Yoshida, M.Iino, T.Takanohashi and K.Kato: Fuel, 79 (2000), 399.

5 ) T.Takanohashi, T.Shishido, I.Saito, K.Masaki, A.Dobashi and K.Fukada: Energy Fuels, 20 (2006), 2552. 
6 ) T.Takanohashi, M.Iino and K.Nakamura: Energy Fuels, 12 (1998), 1168 .

7 ) T.Takanohashi, T.Yoshida and H.Kawashima: Fuel Proc. Technol., 77 (2002), 53.

8 ) K.Ueoka, T.Ogata, Y.Matsushita, H.Aoki, T.Miura, K.Fukuda and K.Matsudaira: Tetsu-to-Hagané, 93 (2007), 728.

9 ) Y.Kubota, S.Nomura, T.Arima and K.Kato: CAMP-ISIJ, 17 (2004), 66.

10) I.Mochida, S.Moriyama, H.Matsuoka, K.Maeda, H.Fujitsu, K.Takeshita and H.Marsh: J. Fuel Soc. Jpn., 58 (1979), 1589.
11) T.Miyagawa and I.Fujishima: J. Fuel Soc. Jpn., 54 (1975), 983.

12) H.Suginobe and T.Miyagawa: Coke Circular, 29 (1980), 159

13) M.Sakai, R.Nishimura, M.Nishimura and K.Fukuda: Tetsu-toHagané, 92 (2006), 164.

14) I.Mochida and Y.Sunami: Tetsu-to-Hagané, 71 (1985), 1589.

15) M.Mihashi, M.Soejima, Y.Asakuma, T.Yamamoto, H.Aoki, T.Miura, K.Kato, S.Itagaki: Tetsu-to-Hagané, 88 (2002), 188.

16) T.Fukuyama, T.Kato and T.Shibuya: Tetsu-to-Hagané, 67 (1981), S106. 